Available online on 15.12.2019 at http://jddtonline.info
Open Access to Pharmaceutical and Medical Research
unrestricted non-commercial use, provided the original work is properly cited

Open@ Access

Review Article

\title{
Pharmacognostical, Phytochemical and Pharmacological profile of Colebrookea oppositifolia Smith
}

\section{Dinesh Kumar Yadav*}

Shree Guru Gobind Singh Tricentenary University, College of Pharmacy, SGT University, Gurugram(Haryana)

\begin{abstract}
Colebrookea oppositifolia commonly known as 'Bhaman' is distributed throughout India from the Himalayas down to Deccan. The plant is used traditionally as such as dermatitis, dysentery, fever, headache, peptic ulcer, haemostatic, wounds, as anti-fertility agent, fungicide, and the roots of the plant has been most widely used for the treatment of epilepsy.. Medicinally, it has been proven to possess various pharmacological activities like treating corneal opacity or conjunctivitis, sore eyes due to its anti-inflammatory properties, cardioprotective, hepatoprotective, anti-inflammatory, antihelmintic, antifungal, antioxidant, antimicrobial, antinociceptive, cytotoxic activity, anticonvulsant, antiulcer, antimicrobial, anti-fertility, antipyretic and insecticide. Further, studies reveal the presence of various phytochemical constituents mainly flavone glycosides viz. chrysin, negletein, landenein; leaves contain 5,6,7- tri-methoxyflavone, 5,6,7,4'-tetramethoxyflavone, acteoside, and quercetin in the bark; root contains stearic, palmitic, oleic acids, triacontanol, flavone glycoside echioidin, 5,6,7-trimethoxyflavone and 4',5,6,7tetra methoxy flavone; sugars and vitamins have also been isolated from this plant. These studies reveal that Colebrookea oppositifolia is a source of medicinally active compounds and have various pharmacological effects; hence, this drug encourage finding its new therapeutic uses.
\end{abstract}

Keywords: Colebrookea oppositifolia, wound healing, anticonvulsant, Lamiaceae

Article Info: Received 06 Oct 2019; $\quad$ Review Completed 14 Nov 2019; $\quad$ Accepted 20 Nov $2019 ; \quad$ Available online 15 Dec 2019

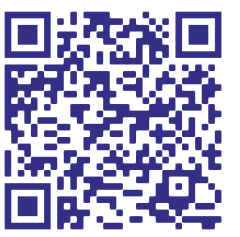

Cite this article as:

Yadav DK, Pharmacognostical, Phytochemical and Pharmacological profile of Colebrookea oppositifolia Smith, Journal of Drug Delivery and Therapeutics. 2019; 9(6-s):233-237 http://dx.doi.org/10.22270/jddt.v9i6-s.3745

\section{*Address for Correspondence:}

Dr. Dinesh Kumar Yadav, Associate Professor (Department of Pharmacognosy), Shree Guru Gobind Singh Tricentenary University, Chandu - Budhera, Gurugram - Badli Road, Gurugram, Haryana - 122505

\section{Introduction:}

Colebrookea oppositifolia is a monotypic genus of Lamiaceae, first described in 1806. The family is represented by 236 genera and 6,900 to 7,200 species, out of which about 400 species are reported from India. The members of this family are well known as aromatic species, as they contain large quantities of the essential oils ${ }^{1}$.It is commonly called as Bhaman or Dosul in local and also known as Indian Squirrel Tail in English. ${ }^{2}$ The plant is evergreen, densely woolly shrubs or small tree, 1.2 to $3.6 \mathrm{~m}$ distributed mostly in subtropical regions of the world such as India, Pakistan, Nepal, Myanmar, Thailand, South west, China and in India widely in Northern and Southern slopes of the Himalayan range of Sikkim at elevation ranging between 3000-5000 ft and it grows wild on hills and plains throughout India mainly occupying subtropical Madhya Pradesh and Deccan Peninsula ${ }^{3}$. It has been extensively used in the traditional system of Indian medicine for the treatment of various ailments such as headache, fever, dysentery, peptic ulcer, dermatitis, wounds, hemostatic, antifungal, as anti-fertility agent, and the roots of the plant has been most widely used for the treatment of epilepsy4,5. In support of potential medicinal uses in folk medicine, various parts of $C$ oppositifolia have been shown to possesses pharmacological activities such as anticonvulsant ${ }^{6}$, antioxidant 7,8 , antiulcer ${ }^{9}$, antimicrobial $^{8}, \quad$ cardioprotective $^{10}$ and anti-fertility 11 activities. Furthermore, confined to the present work, various parts of the plant such as roots, leaves and stem (in the form of decoction and dry powder) are being extensively used for the treatment of epilepsy by various folk medicine practicing communities such as nomadic Gujjars, Tharu and Bhoxa in sub- Himalayan regions of India, from many decades and even now ${ }^{12}$.

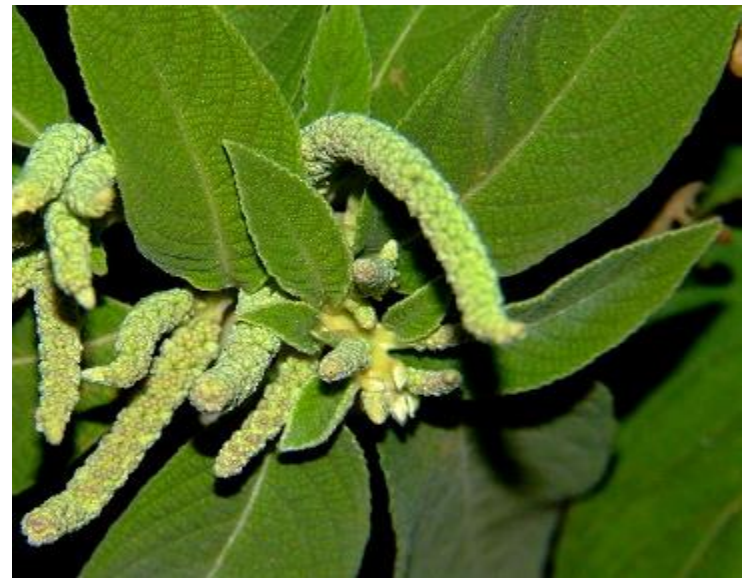

Fig.1. Leaf with flower 
Classification:

$\begin{array}{ll}\text { Kingdom: } & \text { Plantae } \\ \text { Phylum: } & \text { Eudicots } \\ \text { Class: } & \text { Asterids } \\ \text { Order: } & \text { Lamiales } \\ \text { Family: } & \text { Lamiaceae } \\ \text { Genus: } & \text { Colebrookea } \\ \text { Species: } & \text { oppositifolia }\end{array}$

\section{Vernacular names: ${ }^{4}$}

English: Indian squirrel tail

$\begin{array}{ll}\text { Hindi: } & \text { Binda, Kala-bansa, Pansra, Bhirmoli } \\ \text { Telugu: } & \text { Jolidi, Tolisi } \\ \text { Kannada: } & \text { Thuggigida } \\ \text { Marathi: } & \text { Bhaman, Bhamini, Bhamni } \\ \text { Tamil: } & \text { Vitupucittalai } \\ \text { Oriya: } & \text { Tulia } \\ \text { Lepcha: } & \text { Umhyemkung }\end{array}$

\section{Phytogeography:}

The plant is distributed throughout India, Pakistan, Southwest China (Yunnan), Nepal, Myanmar, Thailand, IndoChina. It grows in Savanna forests, thickets in hot, dry regions up to 200-200 meters. The family is represented by 236 genera and 6,900 to 7,200 species, out of which about 400 species are reported from India. The members of this family are well known as aromatic species, as they contain large quantities of the essential oils ${ }^{1}$.

\section{Pharmacognosy:}

The genus Colebrookea belongs to the family: Lamiaceae; Average height of about 1-3 m shrubs which are erect, densely lanate-tomentose. It has pale hairy stout square branches and stems are yellow-brown. Leaves are sometimes in whorls of 3 , oblong-elliptic, dentate. Petiole $(0.8-2.5 \mathrm{~cm})$, leaf blade - $(10-15 \times 3-5 \mathrm{~cm})$, base - broadly cuneate to rounded, margin - crenulated-serrulate, apex long acuminate, adaxially rugulose and puberulent, abaxially densely tomentose to lanate-tomentose. Numerous tiny white flowers occur in panicles of upright spikes - $110-15 \mathrm{~cm}$ long) branches - (4-7 cm); verticillasters - 10-18 flowered, globose; bracteoles - (1 mm), densely tomentose outside, glabrous inside. Flowers - $(2 \mathrm{~mm})$, pistillate: calyx campanulate - $(1.5 \mathrm{~mm}-6 \mathrm{~mm})$ in fruit, tube very short, visibly ribbed; teeth subulate, later spinescent, purple. Corolla tube puberulent, lower lip slightly longer than upper lip, with middle lobe ovate. Stamens inserted on apical part of tube, included. Style $2 \times$ as long as corolla. In bisexual flowers: calyx minute - $(0.6 \mathrm{~mm})$, corolla $(3 \mathrm{~mm})$; upper lip ovate-oblong - $(0.5 \mathrm{~mm})$, straight, emarginate; lower lip elongated, spreading - (1.5 mm), middle lobe ovate-oblong, 2 $x$ as long as ovate lateral lobes. Style erect, slightly longer than corolla. Nutlets are obovoid - $(1 \mathrm{~mm})$, yellow-brown in color, with a small basal white scar. Flowering period ranges from January-March, through March-April.2,4

\section{Taxonomy:}

\section{Key characters for identification of Colebrookea oppositifolia Smith.}

The presence of flowers, ovules enclosed in carpels, crowned by style and stigma, wood consisting of true vessels, classify the plant as an Angiosperm or flowering plant.

Presence of tap root, petiolate leaves, venation of leaf reticulate, vascular bundles arranged in ring, flowers 4 to 5 merous, embryo with two cotyledons group the plant under Magnoliopsida or Dicotyledons.

Perennial and erect habit, woody or herbaceous nature, generally with several stems and with well defined crown, usually less than 5 meters tall, group the plant into shrub category. Presence of perianth in bi or multiseriate, petals united at least at base, group the plant under Sympetaliod dicot or sympetale. Presence of stamens as many as petals or fewer, stamens alternate with petals, corolla irregular, superior ovary, ovary 4-lobed, style arising from between ovary and lobes, fruit usually nutlet, are the characters which identify the plant as belonging to the family Lamiaceae or Labiatae.

The family Lamiaceae consists of 26 genera in South India. Presence of four perfect stamens which are included, calyx 5 partite, with plumose (hairy) lobes, along with dry nutlets having small scar characterise the plant as belonging to the genus Colebrookea Smith. Colebrookea Smith is a monotypic genus represented by one species namely Colebrookea oppositifolia Smith and hence the plant is identified as C. oppositifolia.

\section{Family characters of Lamiaceae}

Herbs or undershrubs, rarely shrubs, usually with aromatic oil glands, branches opposite or verticillate, usually 4angled. Leaves opposite or whorled, simple or rarely pinnatisect, stipules 0 , blade simple, rarely palmatifid; margin usually serrate. Flowers bisexual, more or less zygomorphic, solitary or in pairs or fascicled and axillary, or in centrifugal cymes which by union in pairs form false whorls; bracts and bracteoles usually small. Calyx 4-5-lobed, often forming bi-lipped. Corolla hypogynous, tubular at base, limb 4-5-lobed or bi-lipped, imbricate in bud. Stamens inserted in corolla tube, didynamous or only 2 perfect; anther-cells connate, separate or confluent, dehiscing longitudinally. Disc prominent. Ovary deeply 4-lobed; ovules solitary, anatropous in each locule; style simple, from the center of the ovary between the lobes, slender, 2-fid, sometimes unequally. Fruit of 4 dry,1-seeded nutlets, sometimes 1 or more suppressed, scarred at base. Seed small, erect; albumen scanty or 0; radicle inferior.13,14,15

\section{A. Genus characters of Colebrookea J.E. Smith}

Shrubs, white-tomentose. Leaves opposite or ternate, petiolate, oblong-lanceolate, crenulate. Flowers small; whorl dense-flowered, in paniculate spikes; bracteoles connate. Calyx-tube very short; teeth long, ultimately elongate, capillary and plumose. Corolla small; tube very short; lobes 4, subequal. Stamens 4, very short, included, equal, distant; anthers orbicular, cells confluent. Disc uniform. Ovary 4partite; style 2 -fid, lobes subulate. Fruit 1 or 4 obovoid dry nutlets, with hairy tips; basal scar small.15,16,17

\section{Species characters}

\section{(1) Nomenclature}

Family: Lamiaceae

Genus: Colebrookea J.E.Smith 
Species: Colebrookea oppositifolia Sm., Exot. Bot.2: t. 115.1805, "Colebrookea”; Gamble, Fl. Pres. Madras2: 296. 1957 (repr. ed.). C. ternifolia Roxb., Pl. Cor. t. 245. 1815. ${ }^{17}$

\section{(2) Species description}

Much branched, $1.5-3 \mathrm{~m}$ tall, white-tomentose shrubs; branches sub-quadrangular, grooved. Leaves 4.5-14 x 1.0-3.5 $\mathrm{cm}$, crowded at ends of branchlets, elliptic-lanceolate, acute or shortly acuminate at apex, acute at base, crenulate, softly pubescent; petiole $0.5-2.1 \mathrm{~cm}$ long, pubescent. Flowers white, on 5-10 cm long panicled spikes; verticils 2-6 mm apart; bracts linear, caducous. Calyx up to deeply 5 partite; lobes subulate, hairy. Corolla tube short; lobes 4 , subequal. Stamens 4; filaments in functional male flowers exserted; included in functional female flowers. Pistillode rudimentary in functional male flowers; anthers uniform. Ovary small, 2 loculed, seemingly 4- partite; ovule with 5 hairy subulate lobes. ${ }^{17}$

\section{Microscopical characters}

Transverse section of petiole shows a thin cuticle followed by one layer of rectangular epidermis. Trichomes of various types viz; glandular and non glandular, unicellular and multicellular are found. Next to epidermis lies 4-5 layers of collenchyma, some cells contain unknown nature of cell content. Ground tissue constitutes major part; contain druses type of calcium oxylate crystal, while some other cells contain acicular raphides. Glandular trichomes are sessile or uni-stalked with single head; some glandular cells contain essential oil. The non-glandular trichomes are uniseriate, multicellular and very long. Shorter glandular trichomes, trichome with glandular head are also found. The vascular bundle is made up of xylem and phloem. Transverse section of lamina shows single layer of upper and lower epidermis. Spongy parenchyma consists of 4-6 layers of loosely arranged cells. Transverse section through midrib shows 5-6 layers of collenchyma and many layers of parenchymatous ground tissue. Ground tissue contains rectangular calcium oxalate crystals. Stomata are anisocytic type, found on the upper epidermis ${ }^{2}$.

\section{Phytochemistry:}

Major phytoconstituents of Colebrookea oppositifolia have been reported namely n-triacontane, Cetyl alcohol, 32hydroxydotriacontyl ferulate, $\beta$-sitosterol, 5,6,7,4'tetramethoxyflavone; flavone glycosides viz. Chrysin, Negletein, Landenein; leaves contain 5,6,7- trimethoxy flavone, 5,6,7,4'-tetramethoxyflavone, acteoside, Quercetin in the bark ${ }^{18-21}$; root contains Stearic, Palmitic, Oleic acids, Triacontanol, flavone glycoside echioidin, 5,6,7trimethoxyflavone, and 4',5,6,7- tetramethoxyflavone 2,22-23; sugars and vitamins have also been reported from this plant ${ }^{24}$. Structure of phytoconstituents are given in (Fig. 2)

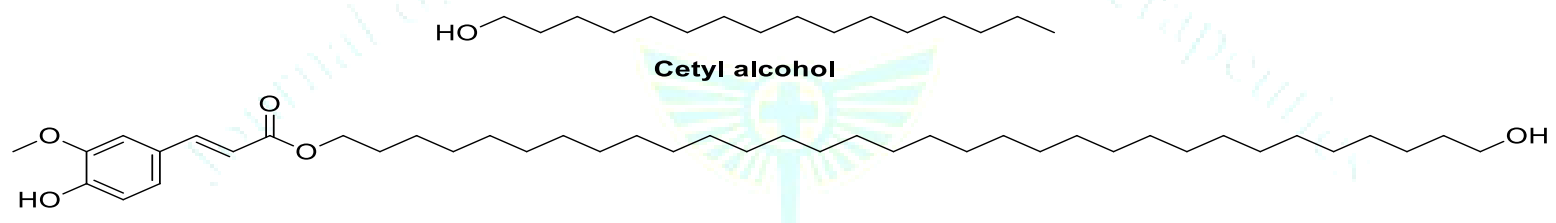

32-Hydroxydotriacontyl ferulate

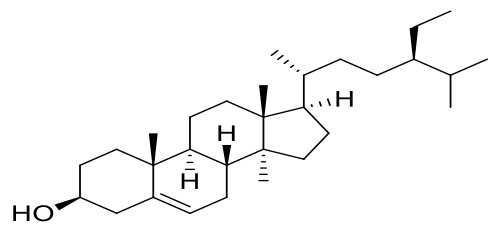

B-Sitosterol<smiles>COc1cc2oc(-c3ccccc3)cc(=O)c2c(O)c1O</smiles>

Negletein<smiles>COc1ccc(-c2cc(=O)c3c(OC)c(OC)c(OC)cc3o2)cc1</smiles>

4',5,6,7-Tetramethoxyflavone<smiles>COc1ccc(-c2cc(=O)c3c(O)c(O)c(OC)cc3o2)cc1</smiles>

Landenein<smiles></smiles><smiles>COc1cc2oc(-c3ccccc3)cc(=O)c2c(OC)c1OC</smiles>

5,6,7-Trimethoxyflavone<smiles>O=c1c(O)c(-c2ccc(O)c(O)c2)oc2cc(O)cc(O)c12</smiles>

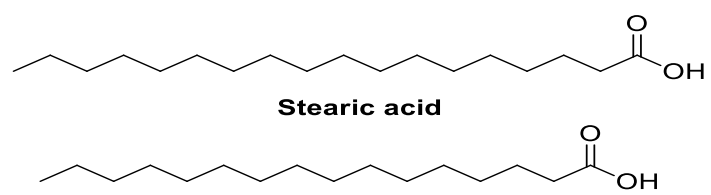

Palmitic acid

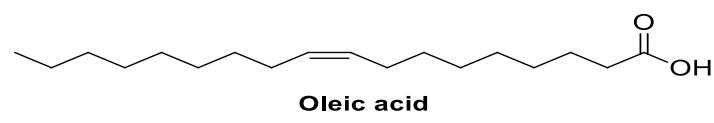




\section{Traditional uses:}

Colebrookea oppositifolia Smith, has been extensively used in the folklore medicine for the treatment of various diseases such as dermatitis, dysentery, fever, headache, peptic ulcer, haemostatic, wounds, as anti-fertility agent, fungicide, urinary problems, hepatitis, anti-microbial and the roots of the plant has been most widely used for the treatment of epilepsy. Leaves are used in the treatment of wounds, bruises and fracture. Leaves are warmed in boiling water and applied on the sprains, given to cattle to eat in anthrax. Leaves are compressed and are applied in toothache. Leaf paste is applied over the fractured bone and also in mouth and tongue sores. The juice of the young inflorescence is given to treat gastric problems and is also put in the nose for sinusitis, oil possesses fungi toxic property. The plant is lopped for fodder to cattle. $4,25-28$

\section{Pharmacological importance:}

\section{Anti-bacterial activity}

Antibacterial activity of shoots, leaves, and roots have been examined against both Gram positive and Gram negative bacteria. Root extract exhibited more antibacterial activity against $B$. cereus, $S$. aureus, K. pneumonia, P. aeruginosa and $S$. flexneri at $37^{\circ} \mathrm{C}$ than leaf and shoot extracts. Chloroform, methanol and water extracts of leaves of the plant have been evaluated for their in vitro antibacterial activity by applying dilution factor of leaf extract on microbial organisms MTCC106 Micrococcus luteus, MTCC1589 Pol /pHYD58 (in E.Coli), MTCC1772 Neisseria mucos and MTCC1658C Trobacter freumdii.

\section{Antifungal activity}

The plants have been reported antifungal activity and showing synergistic relation between amphotericin B (AmB) and acteoside exhibiting antifungal activity has also been reported where acteoside alone failed to produce any intrinsic antifungal effect, thereby proposing a new future combination therapy against fungal infections. The essential oil of Colebrookea oppositifolia possesses fungitoxic property.

\section{Anti-oxidant}

Methanolic extracts of leaves of plants assess the antioxidant effects in various systems; the free radical scavenging potential has been estimated by using different screening models of antioxidants with vitamin $\mathrm{C}$ as standard. The extract of leaves exhibited antioxidant activity in ferrous sulphate induced lipid peroxidation and superoxide scavenging models. The methanolic extract of leaves played a crucial role in the alteration of oxidative stress. 7,8

\section{Antiulcer activity}

Aqueous extract of roots of the plant has been shown the protective effects on peptic ulcer induced by swim stress. Extracts significantly led to the reduction in the ulcer index and a considerable increase in the mucus of the gastric wall. ${ }^{9}$

\section{Anticonvulsant}

Root extracts of the plants has been evaluated for anticonvulsant activity against experimental models of epilepsy. 6

\section{Anti-fertility:}

Leaf extract of the plant has shown a notable decrease in spermatogenesis and antifertility studies with special reference to testicular cell population dynamics. Alcoholic extract of plants showed significant reduction in Seminal vesicles and ventral prostate. Leaf extracts showed on male animals depression of spermatogenesis with special reference to testicular cell population dynamics. Oral administration of leaf extract to male rats brought about a significant loss in testis weight, which is known to be mostly related to the number of spermatids and spermatozoa present in the tissue.6,11

\section{Wound healing:}

Alcohol and aqueous extracts of leaves has been evaluated by using excision and incision models. Wound contraction and period of epithelisation were assessed in excision wound whereas wound breaking strength and WBC count were determined in case of incision wounds. Both extracts exhibited significant wound healing potential. ${ }^{29}$

\section{Bioavailability enhancers:}

Aqueous extract of plants co administered with amoxicillin improve the bioavaialiability. ${ }^{30}$

\section{Conclusion:}

Lamiaceae is one of the largest family comprising 3000 species distributed over 221 genera. This family consists of mainly herbs, rarely shrubs, usually with aromatic oil glands. Twenty six genera represented are in South India. Some of the important genera are, Anisochilus Wall., Ocimum Linn., Orthosiphon Benth., Platystoma Reichb, Geniosporum Wall. Coleus Lour., Hyptis Jacq., Lavendula Linn., Pogostemon Desf., Micromeria Benth., Brunella Linn., Leucas R. Br. and Mentha Linn. Some of the important species are, Anisochilus carnosus Wall, Ocimum americanum Linn., Ocimum gratissimum Linn. , Ocimum teuiflorum (Osimum sanctum) Linn., Geniosporum prostratum Beanth., Hyptis suaveolen Poit., Coleus amboinicus Lour. Lavandula angustifolia Linn., Pogostemon patchouli, Pogostemon benghalensis (Burm. f.) O. Kuntze, Mentha piperita Linn., Leucas linifolia Spreng. and Leucas hirta ( Heyne as Roth) Spreng. Leaves, root, flowers and sometimes whole plant possess medicinal property. The chief constituents reported in this family are flavonoids, glycosides, tannins, amino acids and triterpenoids.

The part used in therapeutic uses of the species are also difference like, Anisochilus carnosus.(whole plant) stimulant, expectorant, diaphoretic and used in dressing wounds; Geniosporum prostratum (whole plant)- as a febrifuge, Hyptis suaveolens (leaves)- externally to treat parasitic skin diseases; Lavandula angustifolia (oil)possesses carminative and stimulant properties; Ocimum americanum (leaf)- paste is used externally for skin diseases, Ocimum tenuiflorum (Osimum sanctum) (leaves) - used in asthma, bronchitis and evaluated for wound healing activity; Pogostemon benghalense (leaves)- juice is reportedly used for treating colic and as a febrifuge. Coleus amboinicus (leaves)- asthma, chronic bronchitis; Mentha piperita (leaves)- to relive local pains and headache. Species like Leucas hirta, Leucas lavendlaefolia, Leonoits neptifolia, hyptis suaveolens, Ocimum gratissimum and Ocimum tenuiflorum possess wound healing activity.

Colebrookea oppositifolia Smith belongs to the family Lamiaceae. It is one of the important medicinal plants used in wounds, cuts, bruises, treatment of fracture, traumatic injuries and rheumatoid arthritis besides having antifertility activity. In the present study, an attempt made to conclude pharmacognostical, phytochemical constituents and pharmacological activity of leaves of $C$. oppositifolia. The identification of the plant material taxonomically and pharmacognostically is important to provide pharmacognostical standards and also to avoid spurious or adulterated drugs. The detailed botanical and 
pharmacognostical studies help in evolving specific diagnostic characters.

\section{References:}

1. Kremer D, Dragojević MI, Stabentheiner E, Vitali D, Kosalec I, Dunkić V, Phytochemical and micromorphological traits of endemic MicromeriapseudocroaticaŠilić (Lamiaceae). Natural Product Comunication. 2012; 7(12):1667-1670.

2. Madhavan, V, Yadav DK, Gurudeva M and Yoganarasimhan S, Pharmacognostical studies on the leaves of Colebrookea oppositifolia Smith. A.Journal of Trad. Medicine., 2011; 6(4):134-144.

3. Rana TS, Ranade SA, The enigma of monotypic taxa and their Taxonomic implications, J. of Current science, 2009; 96(2):25.

4. Nadkarnii KM (1976) Indian Materia Medica (Vols I, II), Popular Prakasan Pvt. Ltd., Bombay, India.

5. Kritikar, K., Basu, B., 2007. Indian Medicinal Plants. International book Publishers, Bombay.

6. Viswanatha GL1, Venkataranganna MV2, Prasad NBL. Ameliorative potential of Colebrookea oppositifolia methanolic root extract against experimental models of epilepsy: Possible role of GABA mediated mechanism. Biomed Pharmacother. 2017; 90:455-465.

7. Riaz, T., Abbasi, M., Shahzadi, T., Rehman, A., Siddiqui, S., Ajaib, M. Colebrookea oppositifolia: A valuable source for natural antioxidants. J. Med. Plants Res. 2011; 5:4180-4187.

8. Subba, B., Basnet, P., Antimicrobial and Antioxidant Activity of Some Indigenous Plants of Nepal. J. Pharmacogn. Phytochem. 2014; 3:62-67.

9. Ghaisas, M., Sharma, S., Ganu, G., Limaye, R., Antiulcer Activity of Colebrookea oppositifolia Sm. Res. J. Pharmacol. Pharmacodynam. 2010; 2:66-70.

10. Pallab, K., Kush, B., Kumar, P., Girraj, T., Kishor, T., Singh, N., Kumar, S., Shivani, G., In vitro - in vivo evaluation of cardioprotective effect of the leaf extract of Colebrookea oppositifolia Sm. J. Global Trend. Pharm. Sci. 2011; 2:310-324.

11. Gupta, R.S., Yadav, R.K., Dixit, V.P., Dobhal, M.P., Antifertility studies of Colebrookea oppositifolia leaf extract in male rats with special reference to testicular cell population dynamics. Fitoterapia. 2001; 72:236-245.

12. Sharma, J., Gairola, S., Gaur, R.D., Painuli, R.M., Siddiqi, T.O., Ethnomedicinal plants used for treating epilepsy by indigenous communities of sub-Himalayan region of Uttarakhand, India. J. Ethnopharmacol. 2013; 150:353-370.
13. Das PK, Nath V, Gode KD and AK Sanyal. Preliminary Phytochemical and Pharmacological studies on C. hirsutus Linn. Indian J Med Res: 1964; 52(3):300.

14. Roma Mitra. Bibliography on Pharmacognosy of Medicinal Plants .Lucknow: 1985; p.138-39.

15. Harborne JB. Phytochemical Methods. London: Chapmans Hall; 1973.

16. Usha kumari J , Navas M ,Dan M . Pharmacognostic studies on Pellionia heyneana. J tropical med plant Dec-2004; 5, p. 259261.

17. Kulkarni SK. Hand Book of Experimental Pharmacology. $3^{\text {rd }}$ ed. New Delhi: Valalbh Prakashan; 1999.

18. F. Yang, X. C. Li, H. Q. Wang and C. R. Yang. Flavonoid glycosides from Colebrookea oppositifolia. Phytochemistry, 1996, 42:867-869.

19. S. A. Aziz, S. A. Siddiqui and A. Zaman, flavones from Colebrookea oppositifolia .Indian J. Chem., 1974, 12:13271328.

20. S. A. Patwardhan and A. S. Gupta, Indian J. Chem., 1981, 20B, 627.

21. S. Ansari, M. P. Dhobal, R. P. Tyagi, B. C. Jhoshi and F. S. K. Barar, Pharmazie, 1982, 37, 70.

22. P. K. Mukherjee, K. Mukherjee, A. C. J. H. Lokkerbol, R. Verpoorte and B. Suresh, J. Nat. Remedies, 2001, 1:21-24.

23. R.V. N. Reddy, B. A. K. Reddy and D. Gunasekar, J. Asian Nat. Prod. Res., 2009, 11:183-186.

24. S. Tyagi, S. Saraf, A. C. Ojha and G. S. Rawat, Asian J. Chem., 1995, 7:165-170.

25. R. S. Gupta, R. K. Yadav, V. P. Dixit and M. P. Dobhal, Fitoterapia, 2001, 72:70.

26. K. Joshi, R. Joshi and A. R. Joshi, Indian J. Tradit. Know., 2011, 10:281-286.

27. S. P. Singh, S. K. Singh and S. C. Tripathi, Indian Perfume, 1983, 27:171-173.

28. J. Holley and K. Cherla, In Medicinal and aromatic plants program in Asia.; Christ opher Samuel Artstock, New Delhi, 1998, 109.

29. V. Madhavan • D.K. Yadav • A. Murali • S.N. Yoganarasimhan.Wound healing activity of aqueous and alcohol extracts of leaves of Colebrookea oppositifolia Smith. Indian drugs, 2009; 36(3):209-13.

30. S.Dash, S.B. Bhise, D. Dhachinamoorthi. Effect of aqueous extract of Colebrookea oppositifolia on Bioavailaibility of Amoxycilline in rabbits.Indian drugs, 2004; (4):231-35. 